\title{
ВИВЧЕННЯ ВПЛИВУ ГУМОРАЛЬНИХ ЧИННИКІВ ФЕТАЛЬНИХ НЕРВОВИХ СТОВБУРОВИХ КЛІТИН НА ЦИТОТОКСИЧНУ АКТИВНІСТЬ СПЛЕНОЦИТІВ ЩУРІВ 3 ЧЕРЕПНО-МОЗКОВОЮ ТРАВМОЮ
}

\author{
๑М. І. Лісяний, Л. М. Бельська, А. В. Паламарьова, Д. М. Станецька, А. І. Ключникова \\ ДУ «Інститут нейрохірургії НАМнУ імені академіка А. П. Ромоданова», Київ
}

PЕЗЮМЕ. В патогенезі ЧМТ традиційно виділяється дві фази. Перша фаза обумовлена пошкодженням головного мозку при прямій дії травмуючого чинника, що призводить до механічного пошкодження цілісності нейронів, глії, судин мозку. Друга фаза, у якій виникають так звані вторинні порушення, починається через кілька годин після ЧМТ і триває від кількох днів до кількох тижнів, характеризується надходженням кальцію в нейрони, утворенням вільних радикалів, оксидантним стресом, синтезом прозапальних цитокінів та розвитком імунопатологічних реакцій, що призводить до некрозу та апоптозу нейронів. Одним з підходів до лікування наслідків ЧМТ є клітинна терапія різними стовбуровими клітинами (СК) та їх гуморальними чинниками, які показали себе як перспективний метод лікування.

Мета - вивчення впливу на цитотоксичну активність спленоцитів щурів у першу та 5 добу після ЧМТ гуморальних чинників, які продукуються в культурі клітин in vitro ембріональними нейрональними клітинами.

Матеріал і методи. В роботі використані статевозрілі щури (n=36), розведені у віварії ДУ «IHX HAMH». Усі роботи з експериментальними тваринами проводили з дотриманням законодавчих норм та вимог Закону України № 3447 IV «Про захист тварин від жорстокого поводження», «Європейської конвенції про захист хребетних тварин, які використовуються для дослідних та інших наукових цілей» (Страсбург, 1986), з урахуванням принципів біоетики та норм біологічної безпеки. Тварин утримували у стандартних умовах акредитованого віварію. Черепномозкову травму у щурів моделювали згідно з рекомендаціями Романова Г. А. та інших (2015) шляхом падіння вантажу (вагою 100 г) з висоти 120 см на голову щурів, що були занаркотизовані внутрішньоочеревинно 0,5 мл суміші кетаміну (70,0 мг/кг) та седазину (15 мг/кг) [22].

У роботі визначали цитотоксичну активність спленоцитів щодо еритроцитів барана за спектрофотометричним методом, описаним [23].

Отримання фракцій кондиційного середовища з культур ембріональних клітин головного мозку щурів проводили за розробленою методикою [24]. Головний мозок вилучений у стерильних умовах з плодів наркотизованих ефіром самиць (Е16-18 день вагітності), звільняли від судин та оболонок та багатократним пікетуванням суспендували в середовищі [24]. Отримані клітинні суспензії висівали на дно пластикових чашок Петрі та культивували 48 годин у поживному середовищі без ембріонального телячої сироватки. Супернатанти культур клітин мозку, так звані кондиційні середовища (КС), використовували для лікування тварин з ЧМТ.

Результати. При ЧМТ у щурів відмічається підвищення прямої та антитілозалежної цитотоксичності клітин селезінки, яка реєструється через 24 години після травми з поступовим подальшим зростанням до 5 доби. Одноразове введення трофічних чинників, які продукуються в культурі клітин ембріональними нервовими клітинами в кондиційне середовище, щурам одразу після травми викликає вірогідне зниження показників обох типів цитотоксичності. Введення кондиційних середовищ ембріональних нервових клітин щурам з чМТ на 1, 2, 3 добу після травми викликає на 5 добу вірогідне гальмування підвищеної прямої та антитілозалежної цитотоксичності, що свідчить про імуносупресивну дію цих трофічних чинників.

Висновок. При ЧМТ у щурів спостерігається підвищення цитотоксичної активності спленоцитів вже через 24 години після травми, яка може бути загальмована введенням трофічних чинників, що продукуються ембріональними клітинами головного мозку щурів.

КлючовІ СлОВА: черепно-мозкова травма; спленоцити; цитотоксична активність; ембріональні нервові клітини.

Вступ. Черепно-мозкова травма (ЧМТ) є дуже поширеним неінфекційним захворюванням, яке при тяжкій формі характеризується великою смертністю та прогресуючою інвалідністю. За даними Всесвітньої організації охорони здоров'я, ЧМТ стане основною причиною смертності та захворюваності людей після 2020 року, що $є$ великим економічним тягарем як для держави, так і для пацієнтів та їх сімей $[1,2]$. У патогенезі ЧМТ традиційно виділяється дві фази. Перша фаза обумовлена пошкодженням головного мозку при прямій дії травмуючого чинника, що призводить до механічного пошкодження цілісності нейронів, глії, судин мозку та виділення запальних медіаторів і нейротрансмітерів, активації мікроглії, дифузної дисфункції нейронів, порушення гематоенцефалічного бар'єру (ГЕБ), крововиливів у мозок та церебральної ішемії $[3,6]$. Друга фаза починається через кілька годин після ЧМТ і триває від кількох днів до кількох тижнів загалом, ця фаза характеризується надходженням кальцію в нейрони, утворенням вільних радикалів, дисфункцією мітохондрій, зростанням рівнів глутамату та аспартату, прозапальних цитокінів та оксидативним стресом, 
Огляди літератури, оригінальні дослідження, погляд на проблему, випадок з практики, короткі повідомлення що призводить до некрозу та апоптозу нейронів $[4,6]$. Другу фазу пошкодження розділяють на ранні, проміжні та пізні підфази (періоди) ЧМТ [5, 7].

Важливим чинником пошкодження нейронів після ЧМТ є розвиток імунного запалення з фагоцитозом та цитолізом нервових клітин, яке викликається моноцитами, макрофагами крові, мікрогліальними клітинами мозку та комплементом. Запальні реакції після ЧМТ можуть тривати досить довго після травми $[3,5,6]$.

Одночасно з розвитком вторинних патологічних реакцій після ЧМТ відбувається стимуляція регенеративних процесів, в першу чергу активації астроцитарних клітин, з розвитком астрогліозу, який направлено призводить до відділення зони пошкодження від здорової паренхіми мозку. Активуються ангіогенез і нейрогенез в головному мозку за рахунок стимуляції проліферації ендогенних стовбурових нервових клітин у субвентрикулярній зоні та в гіпокампі $[4,6,7]$. Однак лише одних ендогенних стовбурових клітин (СК) недостатньо для відновлення функції нейронів або їх заміни в пошкоджених зонах мозку і часто реалізації програм регенерації після ЧМТ заважають імунні та запальні реакції, які гальмують регенеративні процеси [3].

Одним із нових підходів до лікування наслідків ЧМТ є клітинна терапія різними СК, в тому числі і стовбуровими ембріональними нервовими (НСК) та мезенхімальними стовбуровими клітинами (МСK), які показали себе перспективним засобом для лікування різних захворювань, включаючи і черепно-мозкову травму $[2,8,9]$. Трансплантовані СК при чМТ чинять різнобічну дію на пошкоджену паренхіму головного мозку [10-14]. Необхідно зазначити, що встановлено позитивний вплив на процеси відновлення мозку після ЧМТ не лише стовбурових клітин, а й супернатантів культур СК, в яких клітини культивувались іп vitro протягом певного терміну, так звані кондиційні середовища (КС) [15-17]. При внутрішньовенному введені КС, які були отримані з МСК, тваринам з ЧМТ, спостерігалось покращення неврологічних функцій, що пов'язано зі сприянням ендогенному ангіогенезу та нейрогенезу, а також зниженням запальної реакції після травми [1820]. Водночас, багато питань про механізми дії самих стовбурових клітин та їх гуморальних чинників на імунопатологічні та репаративні процеси в мозку після ЧМТ, в тому числі на системні імунні реакції, на цитотоксичні, кілерні клітини в організмі після ЧМТ ще до кінця не вивчені $[17,20]$. Вирішення цих задач, можливо, сприятиме повнішому розумінню патогенезу ЧМТ та створенню нових ефективних методів та препаратів для лікування ЧМТ.

Мета - вивчення впливу на цитотоксичну активність спленоцитів щурів на 1 та 5 добу після ЧМТ гуморальних чинників, які продукуються в культурі клітин in vitro ембріональними нервовими клітинами.

Матеріал і методи дослідження. В роботі використані експериментальні тварини, статевозрілі щури (n=36), розведені у віварії ДУ «ІНХ НАМН». Усі роботи з експериментальними тваринами проводили з дотриманням законодавчих норм та вимог Закону України № 3447 IV «Про захист тварин від жорстокого поводження», «Європейської конвенції про захист хребетних тварин, які використовуються для дослідних та інших наукових цілей» (Страсбург, 1986), з урахуванням принципів біоетики та норм біологічної безпеки. Тварин утримували у стандартних умовах акредитованого віварію. Знеболювання та евтаназію проводили під ефірним наркозом. Проведення дослідження затверджене комісією з етики та біоетики Інституту нейрохірургії імені акад. А. П. Ромоданова НАМН України (протокол № 26 від 11 травня 2018 р.).

Черепно-мозкову травму у щурів моделювали згідно з рекомендаціями Романова Г. А. та інших (2015) [21] з моделювання ЧМТ у тварин шляхом падіння вантажу (вагою 100 г) з висоти 120 см на голову щурів, що були занаркотизовані внутрішньочеревно 0,5 мл суміші кетаміну 70,0 мг/кг та седазину 15 мг/кг [21]. Через 20-30 хв тварини виходили із наркозу та починали рухатись і їх повертали до клітки та умов, в яких вони знаходились до початку досліду.

Визначення цитотоксичної активності клітин селезінки у щурів.

Цитотоксичні клітини $є$ ефекторними імунними клітинами, які діляться на такі субпопуляції як кілерні клітини, НК, цитотоксичні лімфоцити, макрофаги, цитотоксичні нейтрофіли, індуковані лектинами кілерні клітини та інші типи [23]. В якості клітин-мішеней використовують різні клітини (тимоцити, спленоцити, макрофаги, еритроцити, пухлинні клітини). Найчастіше при визначенні цитотоксичності для виявлення інтенсивності цитолізу використовують радіоактивні ізотопи або гемоглобін еритроцитів. У нашій роботі у дослідних і контрольних зразках визначали цитотоксичну активність клітин щодо еритроцитів барана за спектрофотометричним методом, описаним [24]. При визначенні прямої цитотоксичності (ПЦ) клітин використовували 500,0 мкл 0,1% суміші еритроцитів барана та 500,0 мкл суспензії спленоцитів щурів у кількості 2,0×106 клітин 1,0 мл приготовлених на 199 середовищі. Співвідношення клітин-ефекторів та клітин-мішеней в пробі складало 2:1. Культивування суміші клітин тривало 18 годин. Процент зруйнованих клітин-мішеней (еритроцитів барана) 
Огляди літератури, оригінальні дослідження, погляд на проблему, випадок з практики, короткі повідомлення вимірювали за кількістю гемоглобіну, який вивільнився в супернатант із еритроцитів, на спектрофотометрі С $ф-24$ при довжині хвилі 402 нм.

Процент лізису вимірювали за формулою:

ЦА ум.од = Д - Сп /МЛ - Сп, де Д - кількість гемоглобіну в супернатантах дослідних зразків; Сп - кількість гемоглобіну в супернатантах спонтанно зруйнованих еритроцитів; МЛ - максимальний лізис, це загальна кількість гемоглобіну в $2 \times 10^{6}$ еритроцитів при $100 \%$ лізисі, який викликався $\mathrm{H}_{2} \mathrm{O}$.

Антитілозалежна клітинна цитотоксичність (АЗКЦ), що розглядається як один із різновидів клітинної цитотоксичності, детально описана Millek (1987) [23], де ефекторні цитотоксичні клітини діють неспецифічно, зв'язуючись з комплексом антиген-антитіло на поверхні клітини-мішені. Специфічність цитотоксичної реакції визначається антигенною направленістю антитіл. У роботі використовували в якості комплексу антиген-антитіло еритроцити барана та гемолітичну сироватку проти еритроцитів в субаглютинуючому титрі згідно з інструкцією виробника (НПО «Биомед", Пермь, Россия). 500,0 мкл суміші 0,1% еритроцитів та гемолітичної сироватки інкубували $з$ 500,0 мкл спленоцитів в кількості 2,0×106 клітин 1,0 мл приготованих на 199 середовищі.

Культивування суміші ефекторів та мішеней тривало 18 годин. Процент зруйнованих клітинмішеней (еритроцитів) вимірювали на С $ф-24$ при хвилі 402 нм за кількістю зруйнованого гемоглобіну, який вийшов з еритроцитів. Антитілозалежну цитотоксичність визначали за наведеною вище формулою для прямої цитотоксичності.

Отримання фракцій кондиційного середовища з культур ембріональних клітин головного мозку щурів проводили за розробленою нами методикою [21]. Коротко методика полягає в наступному. Головний мозок, вилучений у стерильних умовах з плодів наркотизованих ефіром самиць у визначений термін вагітності (E16-18, n=14), промивали у середовищі DMEM («Sigma»), звільняли від судин та оболонок, переносили у свіже живильне середовище і механічно дисоціювали багатократним піпетуванням [21]. Отримані клітинні суспензії фільтрували через капроновий фільтр та осаджували центрифугуванням при 1000,0 об/хв тривалістю 5 хв та ресуспендували у середовищі DMEM. Надалі клітини в дозі 4×106 кл/мл висівали на дно пластикових чашок Петрі та культивували 48 годин в поживному середовищі без ембріональної телячої сироватки. Супернатанти культур ембріональних клітин мозку, так звані кондиційні середовища, забирали із культуральних чашок, об'єднували та відділяли від клітинних домішок методом центрифугування, визначали рівень біл-

ка на СФ і зберігали при -20 С у пробірках по 2,0 мл [21].

Схема експерименту була наступною. Тварини були поділені на 3 групи: 1 група - тварини з ЧМТ, яких лікували кондиційним середовищем (КС), що отримували з фракції ембріональних нейрональних клітин мозку (НСК); 2 група (група порівняння) тварини з ЧМТ, що отримували лише поживне середовище 199; 3 групу склали інтактні тварини без травми. Лікування кондиційним середовищем, яке одержували після культивування НСК, починали через одну годину та на 2, 3 добу після нанесення травми. Тваринам вводили по 1,0 мл отриманих КС (супернатантів) НСК внутрішньом'язово з вмістом в 1,0 мл КС 0,28 мг/мл білка, який визначався спектрофотометричним методом при 280 та 260 нм на СФ-24. Через 24 години після травми та першого введення КС, а також на 5-у добу після ЧМТ та 3-разового введення КС тварин умертвляли ефіром та забирали селезінку, з якої готували суспензію клітин за загальноприйнятим методом на 199 середовищі, кількість клітин селезінки після однократного відмивання та фільтрації через капроновий фільтр підраховували із 3 \% оцтовою кислотою в камері Горяєва. В реакціях цитотоксичності використовували по 2×106 клітин селезінки в 1 мл 199 середовища.

Статистичну обробку отриманих даних проводили за допомогою комп'ютерних програм Microsoft Excel 2010 і Statistica 6.1. Статистичну значущість відмінностей оцінювали з використанням непарного непараметричного U-критерію Манна - Уїтні. Різницю між досліджуваними показниками вважали статистично значущою при $\mathrm{p}<0,05$.

Результати й обговорення. Дослідження показників ПЦ та АЗЦ спленоцитів у інтактних тварин при 24-годинній постановці реакції показало, що АЗЦ у 2-2,5 рази вища від прямої цитотоксичності, що пояснюється важливою роллю Fс-рецептора на цитотоксичних клітинах, який сприяє активності кілерних клітин. При легкій ЧМТ у щурів виникає вже через 24 години стимуляція ПЦ у 2,5 раза $(p<0,05)$ та АЗЦ у 1,5 раза ( $<<0,05)$, що свідчить про швидку активізацію кілерної активності, яка обумовлена ранньою прозапальною реакцією як в головному мозку, так і в усьому організмі. Привертає увагу те, що ПЦ спленоцитів збільшилось у 2,5 раза, а АЗЦ значно менше, всього у 1,5 раза, це може вказувати на те, що клітини, які викликають пряму цитотоксичність значно швидше активуються, а це дозволяє думати, що це різні популяції клітин, які неоднаково реагують на прозапальну реакцію, що виникає після ЧМТ. Показники як ПЦ, так і АЗЦ на 5 добу після ЧМТ продовжують відповідно зростати, порівняно з показниками цитотоксичності, яка 
Огляди літератури, оригінальні дослідження, погляд на проблему, випадок з практики, короткі повідомлення спостерігається на першу добу після травми, що свідчить про збереження запальної реакції в цей час, хоча, за даними літератури, після 3 доби спостерігається як зниження синтезу прозапальних цитокінів, так і гальмування імунних реакцій $[3,6,25]$.

Цитотоксична здатність спленоцитів може бути пов'язана з різними субпопуляціями клітин, які $\epsilon$ в селезінці, а саме з лімфоцитами, моноцитами, дендритними клітинами та нейтрофілами $[21,25]$, які здатні прямим контактом чи опосередковано, через антитіла, діяти на клітини-мішені та викликати їх загибель шляхом лізису чи некрозу або апоптозу. Можливо, активовані цитотоксичні клітини селезінки можуть мігрувати в зони ушкодження, наприклад, як нейтрофіли та лімфоцити, і обумовлювати вторинні імунологічні реакції в головному мозку, які проявляються некрозом та

нейродегенералізацією нервових клітин на 3-10 добу після ЧМТ $[11,25]$.

Введення щурам через 30 хвилин після ЧМТ кондиційного середовища культур НСК провокує зниження показників ПЦ та АЗЦ вже через 24 години, порівняно з тваринами з ЧМТ, яким не вводили КС, однак показники ПЦ та АЗЦ у щурів, які отримували ЧМТ та КС, були вірогідно вищими, ніж показники інтактних тварин. Триразове введення кондиційних середовищ НСК на 1, 2, 3 доби після ЧМТ викликало повне гальмування антитілозалежної цитотоксичності спленоцитів до рівня інтактних тварин. ПЦ спленоцитів у цих тварин була на 5 добу дещо збільшена, але вірогідної різниці з показниками інтактних тварин не було, це свідчить, що введені кондиційні середовища зменшують як ПЦ, так і АЗЦ спленоцитів (табл. 1).

Таблиця 1. Показники прямої та антитілозалежної цитотоксичності спленоцитів щурів із чМТ та дії трофічних чинників НСК (ум. Од, М+m)

\begin{tabular}{|c|c|c|c|c|}
\hline Термін після ЧМТ & № групи & Групи тварин & Пряма цитотоксичність & $\begin{array}{l}\text { Антитілозалежна } \\
\text { цитотоксичність }\end{array}$ \\
\hline 1 доба & $\begin{array}{l}1 \\
2 \\
3\end{array}$ & $\begin{array}{c}\text { Інтактні } \\
\mathrm{n}=10 \\
\text { ЧМТ } \\
\mathrm{n}=5 \\
\text { ЧМТ+ HCK } \\
\mathrm{n}=4\end{array}$ & $\begin{array}{c}11,88 \pm 0,71 \\
24,106 \pm 0,97 \\
P_{1,2}<0,00067 \\
18,405 \pm 1,08 \\
P_{1,3}<0,0005 \\
P_{2,3}<0,032\end{array}$ & $\begin{array}{c}21,49 \pm 0,94 \\
30,418 \pm 0,6 \\
\mathrm{P}_{1,2}<0,00067 \\
25,108 \pm 1,32 \\
\mathrm{P}_{1,3}<0,00003 \\
\mathrm{P}_{2,3}<0,01\end{array}$ \\
\hline 5 доба & $\begin{array}{l}4 \\
5\end{array}$ & $\begin{array}{c}4 \mathrm{MT} \\
\mathrm{n}=12 \\
\mathrm{MMT}+\mathrm{HCK} \\
\mathrm{n}=4\end{array}$ & $\begin{array}{c}27,129 \pm 1,13 \\
P_{1,4}<0,0005 \\
15,190 \pm 1,8 \\
P_{1,5}>0,05 \\
P_{4,5}<0,016\end{array}$ & $\begin{array}{c}42,21 \pm 1.96 \\
\mathrm{P}_{1,4}<0,00003 \\
19,95 \pm 1,71 \\
\mathrm{P}_{1,5}>0,05 \\
\mathrm{P}_{4,5}<0,0003\end{array}$ \\
\hline
\end{tabular}

Проведеними дослідженнями встановлено, що як пряма, так і антитілозалежна цитотоксична активність спленоцитів, яка може бути обумовлена лімфоцитами, макрофагами та іншими імунними клітинами [23, 24], збільшується в перші години після ЧМТ і зберігається до 5 доби, що свідчить про можливе залучення системних імунних реакцій, а саме клітин селезінки, до патологічних місцевих процесів у головному мозку, які виникають після ЧМТ $[25,26]$.

В роботі показано, що цитотоксична активність спленоцитів може бути загальмована як одноразовим, так і трикратним введенням кондиційних середовищ культур НСК. Ефект гальмування цитотоксичності проявляється уже через 24 години після введення трофічних факторів. Необхідно зазначити, що триразове введення КС на 1, 2, 3 добу після ЧМТ повністю гальмувало цитотоксичність спленоцитів до рівня інтактних, здорових тварин, що вказує, що фактори, які присутні в КС, проявляють протизапальні властивості, мож- ливо, гальмують чи блокують синтез прозапальних цитокінів після ЧМТ, що характерно для трофічних факторів, які можуть синтезуватись різними типами СК [18-21].

Отже, активація цитотоксичних реакцій, які обумовлені клітинами селезінки, розвивається вже з першої доби після чМТ, може бути свідченням участі цих клітин у другій фазі патогенезу ЧМТ [3-6], яка проявляється не лише в зоні ушкодження головного мозку, а й змінами в системних імунних реакціях, а саме активацією цитотоксичних клітин у селезінці. Гуморальні чинники, які синтезуються НСК в культурі ex vivo, гальмують цитотоксичну активність спленоцитів, що вказує на можливість за допомогою гуморальних факторів керувати підвищеною клітинною цитотоксичністю, яка виникає після ЧМТ, а також на використання вказаних чинників як основи для пошуку нових заходів лікування травми.

Висновки. 1. При ЧМТ у щурів відмічається підвищення прямої та антитілозалежної цитотоксичності клітин селезінки, яка реєструється з пер- 
Огляди літератури, оригінальні дослідження, погляд на проблему, випадок з практики, короткі повідомлення шої доби після травми з поступовим зростанням до 5 доби. Через добу після ЧМТ показники прямої клітинної цитотоксичності зростали більше ніж у 2 рази, тоді як антитілозалежна цитотоксичність спленоцитів у 1,5 раза, в порівняні з тваринами без травми, а це може вказувати на те, що це різні типи цитотоксичних клітин, які $\epsilon$ в селезінці.

2. Одноразове введення трофічних чинників, які продукуються в поживне середовище в культурі ембріональними нервовими клітинами, щурам одразу після травми викликає вірогідне зниження показників обох типів цитотоксичності вже на першу добу після травми.

\section{ЛІТЕРАТУРА}

1. Traumatic brain injury: integrated approaches to improve prevention, clinical care, and research / A. I. R. Maas, D. K. Menon, P. D. Adelson [et al.] // Lancet Neurol. 2017. - Vol. 16 (12). - P. 987-1048. DOI: 10.1016/ S1474-4422(17)30371-X.

2. Advance of stem cell treatment for traumatic brain injury / Y. Zhou, A. Shao, W. Xu [et al.] // Front. Cell Neurosci. - 2019. - Vol. 13. - P. 301. DOI: 10.3389/ fncel.2019.00301.

3. Dynamic imaging in mild traumatic brain injury: support for the theory of medial temporal vulnerability / E. M. Umile, M. E. Sandel, A. Alavi [et al.] // Arch. Phys. Med. Rehabil. - 2002. - Vol. 83 (11). - P. 1506-1513. DOI: $10.1053 /$ apmr.2002.35092.

4. Kelley B. J. Neuroinflammatory responses after experimental diffuse traumatic brain injury / B. J. Kelley, J. Lifshitz, J. T. Povlishock // J. Neuropathol. Exp. Neurol. 2007. - Vol. 66 (11). - P. 989-1001. DOI: 10.1097/ NEN.0b013e3181588245.

5. Algattas H. Traumatic Brain Injury pathophysiology and treatments: early, intermediate, and late phases postinjury / H. Algattas, J. H. Huang // Int. J. Mol. Sci. - 2013. Vol. 15 (1). - P. 309-341. DOI: 10.3390/ijms15010309.

6. Hippocampal pathology in fatal human head injury without high intracranial pressure / M. J. Kotapka, D. I. Graham, J. H. Adams, T. A. Gennarelli // J. Neurotrauma. - 1994. Vol. 11 (3). - P. 317-324. DOI: 10.1089/neu.1994.11.317.

7. Ugoya S. O. Bench to bedside of neural stem cell in traumatic brain injury / S. O. Ugoya, J. Tu // Stem. Cells. Int. 2012. - Vol. 2012. - P. 141624. DOI: 10.1155/2012/141624.

8. Autologous bone marrow mononuclear cells therapy attenuates activated microglial/macrophage response and improves spatial learning after traumatic brain injury / S. S. Bedi, P. A. Walker, S. K. Shah [et al.] // J. Trauma Acute Care Surg. - 2013b. - Vol. 75. - P. 410-416. DOI: 10.1097/ TA.0b013e31829617c6.

9. Stem cell biology in traumatic brain injury: effects of injury and strategies for repair / R. M. Richardson, A. Singh, D. Sun [et al.] // J. Neurosurg. -2010. -Vol. 112 (5). P. 1125-1138. DOI: 10.3171/2009.4.JNS081087.

10. Trauma-associated inflammatory response impairs embryonic stem cell survival and integration after implanta-

3. Введення кондиційних середовищ ембріональних нервових клітин щурам з ЧМТ на 1, 2, 3 доби після травми викликає на 5 добу гальмування підвищеної прямої та антитілозалежної цитотоксичності до рівня показників інтактних здорових тварин, що свідчить про імуносупресивну дію цих трофічних чинників.

4. Подальше вивчення умов отримання та природи трофічних чинників, які виділяються HCK in vitro в культурі клітин в поживне середовище може стати основою для пошуку та розробки нових препаратів із стовбурових клітин для лікування ЧМТ.

tion into injured rat brain / M. Molcanyi, P. Riess, K. Bentz [et al.] // J. Neurotrauma. - 2007. - Vol. 24 (4). - P. 625-637. DOI: 10.1089/neu.2006.0180.

11. Cox C. S. Jr. Cellular therapy for traumatic neurological injury / C. S. Jr. Cox // Pediatr. Res. - 2018. - Vol. 83 (1-2). - P. 325-332. DOI: 10.1038/рr.2017.253.

12. Lisaniy M. I. Clinical therapy for experimental craniocerebral trauma / M. I. Lisaniy // Ukr. Neurosurg. J. 2020. - Vol. 26 (2). - P. 5.

13. Chopp M. Treatment of neural injury with marrow stromal cells / M. Chopp, Y. Li. // Lancet Neurol. - 2002. Vol. 1 (2). - P. 92-100. DOI: 10.1016/s1474-4422(02)00040-6.

14. Xiong Y. Emerging potential of exosomes for treatment of traumatic brain injury / Y. Xiong, A. Mahmood, M. Chopp // Neural. Regen. Res. - 2017. - Vol. 12 (1). P. 19-22. DOI: 10.4103/1673-5374.198966.

15. Human bone marrow stromal cell cultures conditioned by traumatic brain tissue extracts: growth factor production / X. Chen, M. Katakowski, Y. Li [et al.] // J. Neurosci. Res. -2002. - Vol. 69 (5). - P. 687-691. DOI: 10.1002/ jnr.10334.

16. Systemic administration of exosomes released from mesenchymal stromal cells promote functional recovery and neurovascular plasticity after stroke in rats / H. Xin, Y. Li, Y. Cui [et al.] // J. Cereb. Blood. Flow. Metab. - 2013. Vol. 33 (11). - P. 1711-1715. DOI: 10.1038/jcbfm.2013.152.

17. Hypoxic preconditioning enhances the therapeutic potential of the secretome from cultured human mesenchymal stem cells in experimental traumatic brain injury / C. P. Chang, C. C. Chio, C. U. Cheong [et al.] // Clin. Sci. (Lond). 2013. - Vol. 124 (3). - P. 165-176. DOI: 10.1042/CS20120226.

18. Effect of exosomes derived from multipluripotent mesenchymal stromal cells on functional recovery and neurovascular plasticity in rats after traumatic brain injury / Y. Zhang, M. Chopp, Y. Meng [et al.] // J. Neurosurg. - 2015. Vol. 122 (4). - P. 856-867. DOI: 10.3171/2014.11.JNS14770.

19. Systemic administration of cell-free exosomes generated by human bone marrow derived mesenchymal stem cells cultured under 2D and 3D conditions improves functional recovery in rats after traumatic brain injury / Y. Zhang, M. Chopp, Z. G. Zhang [et al.] // Neurochem. Int. - 2017. Vol. 111. - P. 69-81. DOI: 10.1016/j.neuint.2016.08.003. 
Огляди літератури, оригінальні дослідження, погляд на проблему, випадок з практики, короткі повідомлення

20. Романова Г. А. Моделирование черепно-мозговой травмы / Г. А. Романова, Ф.М.Шакова, А. Л. Парфенова // Патологическая физиология и эспериментальная терапия - 2015. - Т. 59, № 2. - С. 112-115.

21. Вплив трофічних факторів, які продукуються фетальними нервовими клітинами, на розвиток апоптозу у головному мозку щурів після ЧМТ / М. І. Лісяний, Л. М. Бельська, А. О. Лісяний, Д. М. Станецька // Південноукраїнський медичний науковий журнал. - 2021. T. 29, № 1. - С. 60-65.

22. Шульце Х. Ф. Цитотоксические лимфоциты / Х. Ф. Шульце // Иммунологические методы / под. ред. Фримеля Г. - 1987. - С. 283-293.

23. Миллек Ю. Антителозависимая цитотоксичность / Ю. Миллек // Иммунологические методы / под. ред. Фримеля Г. - 1987. - С. 205-213.

\section{REFERENCES}

1. Maas, A.I.R., Menon, D.K., Adelson, P.D., Andelic, N., Bell M.J., Belli A., ..., \& Ercole, A. (2017). Traumatic brain injury: integrated approaches to improve prevention, clinical care, and research. Lancet Neurol., 16 (12), 987-1048. DOI: 10.1016/S1474-4422(17)30371-X.

2. Zhou, Y., Shao, A., Xu, W., Wu, H., \& Deng, Y. (2019). Advance of Stem Cell Treatment for Traumatic Brain Injury. Front. Cell Neurosci., 13, 301. DOI: 10.3389/fncel.2019. 00301.

3. Umile, E.M., Sandel, M.E., Alavi, A., Terry, C.M., \& Plotkin, R.C. (2002). Dynamic imaging in mild traumatic brain injury: support for the theory of medial temporal vulnerability. Arch. Phys. Med. Rehabil., 83 (11), 1506-1513. DOI: 10.1053/apmr.2002.35092.

4. Kelley, B.J., Lifshitz, J., \& Povlishock, J.T. (2007). Neuroinflammatory responses after experimental diffuse traumatic brain injury. J. Neuropathol. Exp. Neurol., 66 (11), 989-1001. DOI: 10.1097/NEN.0b013e3181588245.

5. Algattas, H., \& Huang, J.H. (2013). Traumatic Brain Injury pathophysiology and treatments: early, intermediate, and late phases post-injury. Int. J. Mol. Sci., 15 (1), 309341. DOI: 10.3390/ijms15010309.

6. Kotapka, M.J., Graham, D.I., Adams, J.H., \& Gennarelli, T.A. (1994). Hippocampal pathology in fatal human head injury without high intracranial pressure. J. Neurotrauma, 11 (3), 317-324. DOI: 10.1089/neu.1994.11.317.

7. Ugoya, S.O., \& Tu, J. (2012). Bench to bedside of neural stem cell in traumatic brain injury. Stem Cells Int., 2012, 141624. DOI: 10.1155/2012/141624.

8. Bedi, S.S., Walker, P.A., Shah, S.K., Jimenez, F., Thomas, C.P., Smith, P., ..., \& Wenzel, PL. (2013b). Autologous bone marrow mononuclear cells therapy attenuates activated microglial/macrophage response and improves spatial learning after traumatic brain injury. J. Trauma Acute CareSurg.,75,410-416.DOI:10.1097/TA.0b013e31829617c6.

9. Richardson, R.M., Singh, A., Sun, D., Fillmore, H.L., Dietrich, D.W. 3rd, \& Bullock, M.R. (2010). Stem cell biology in traumatic brain injury: effects of injury and strategies for repair. J. Neurosurg., 112 (5), 1125-1138. DOI: 10.3171/2009.4.JNS081087.

10. Molcanyi, M., Riess, P., Bentz, K., Maegele, M., Hescheler, J., Schäfke, B., ..., \& Schäfer, U. (2007). Trauma-as-
24. Мельников О. Ф. Сравнение радиоизотопного и спектрофотометрического методов определения цитотоксичности клеток / О. Ф. Мельников, Т. А. Заяц // Лабораторная диагностика. - 1999. - № 1. - С. 43-45.

25. Клеточно-молекулярные механизмы изменения защитных функций организма при черепно-мозговой травме и попытка лечения / Е. Г. Рыбакина, С. Н. Шанин, Е. Е. Фомичева [и др.] // Медицинский академический журнал. - 2014. - Т. 14, № 4. - С. 55-61.

26. Лісяний М. І. Особливості розвитку запальних реакцій у кіркових та підкіркових відділах головного мозку щурів після легкої черепно-мозкової травми / М. І. Лісяний, А. В. Паламарьова, А.О.Лісяний // Здобутки клінічної та експериментальної медицини. - 2021. № 1. - С. 92-95.

sociated inflammatory response impairs embryonic stem cell survival and integration after implantation into injured rat brain. J. Neurotrauma, 24 (4), 625-637. DOI: 10.1089/ neu.2006.0180.

11. Cox, C.S. Jr. (2018). Cellular therapy for traumatic neurological injury. Pediatr. Res., 83 (1-2), 325-332. DOI: 10.1038/pr.2017.253.

12. Lisaniy, M.I. (2020). Clinical therapy for experimental craniocerebral trauma. Ukr. Neurosurg. J., 26 (2), 5.

13. Chopp, M., \& Li, Y. (2002). Treatment of neural injury with marrow stromal cells. Lancet Neurol., 1 (2), 92-100. DOI: 10.1016/s1474-4422(02)00040-6.

14. Xiong, Y., Mahmood, A., \& Chopp, M. (2017). Emerging potential of exosomes for treatment of traumatic brain injury. Neural. Regen. Res., 12 (1), 19-22. DOI: $10.4103 / 1673-5374.198966$.

15. Chen, X., Katakowski, M., Li, Y., Lu, D., Wang, L., Zhang, L., ..., \& Chopp, M. (2002). Human bone marrow stromal cell cultures conditioned by traumatic brain tissue extracts: growth factor production. J. Neurosci. Res., 69 (5), 687-691. DOI: 10.1002/jnr.10334.

16. Xin, H., Li, Y., Cui, Y., Yang, J.J., Zhang, Z.G., \& Chopp, M. (2013). Systemic administration of exosomes released from mesenchymal stromal cells promote functional recovery and neurovascular plasticity after stroke in rats. J. Cereb. Blood. Flow. Metab., 33 (11), 1711-1715. DOI: $10.1038 / j \mathrm{jbfm} .2013 .152$.

17. Chang, C.P., Chio, C.C., Cheong, C.U., Chao, C.M., Cheng, B.C., \& Lin, M.T. (2013). Hypoxic preconditioning enhances the therapeutic potential of the secretome from cultured human mesenchymal stem cells in experimental traumatic brain injury. Clin. Sci. (Lond), 124 (3), 165-176. DOI: $10.1042 / C S 20120226$.

18. Zhang, Y., Chopp, M., Meng, Y., Katakowski, M., Xin, H., Mahmood, A., \& Xiong, Y. (2015). Effect of exosomes derived from multipluripotent mesenchymal stromal cells on functional recovery and neurovascular plasticity in rats after traumatic brain injury. J. Neurosurg., 122 (4), 856-867. DOI: 10.3171/2014.11.JNS14770.

19. Zhang, Y., Chopp, M., Zhang, Z.G., Katakowski, M., Xin, H., Qu, C., ..., \& Xiong, Y. (2017). Systemic administration of cell-free exosomes generated by human bone mar- 
Огляди літератури, оригінальні дослідження, погляд на проблему, випадок з практики, короткі повідомлення row derived mesenchymal stem cells cultured under 2D and 3D conditions improves functional recovery in rats after traumatic brain injury. Neurochem. Int., 111, 69-81. DOI: 10.1016/j.neuint.2016.08.003.

20. Romanova, G.A., Shakova, F.M., \& Parfenova, A.L. (2015). Modelirovaniye cherepno-mozgovoy travmy [Modeling of traumatic brain injury]. Patologicheskaya fiziologiya i esperimentalnaya terapiya - Pathological Physiology and Experimental Therapy, 59, 2, 112-115 [in Russian].

21. Lisianyi, M.I., Belska, L.M., Lisianyi, A.O., \& Stanetska, D.M. (2021). Vplyv trofichnykh faktoriv, yaki produkuiutsia fetalnymy nervovymy klitynamy na rozvytok apoptozu u holovnomu mozku shchuriv pislia CHMT [The effect of trophic factors produced by fetal nerve cells on the development of apoptosis in the brain of rats after trauma]. Pivdennoukrainskyi medychnyi naukovyi zhurnal South Ukrainian Medical Scientific Journal, 29, 1, 60-65 [in Ukrainian].

22. Shultse, Kh.F., \& Frimel, G. (1987). Tsitotoksicheskiye limfotsiti. V kn. "Immunologicheskiye metody" [Cytotoxic lymphocytes. In the book "Immunological methods"] [in Russian].

23. Millek, Yu., \& Frimel, G. (1987). Antitelozavisimaya tsitotoksichnost [Antibody-dependent cytotoxicity]. $V \mathrm{kn}$.

"Immunologicheskiye metody" [Cytotoxic lymphocytes. In the book "Immunological methods"] [in Russian].

24. Melnikov, O.F., \& Zayats, T.A. (1999). Sravneniye radioizotopnogo i spektrofotometricheskogo metodov opredeleniya tsitotoksichnosti kletok [Comparison of radioisotope and spectrophotometric methods for determining cell cytotoxicity]. Laboratornaya diagnostika - Laboratory Diagnostics, 1, 43-45 [in Russian].

25. Rybakina, Ye.G., Shanin, S.N., Fomichevya, Ye.Ye., Filatenkova, T.A., \& Dmitriyenko, Ye.V. (2014g). Kletochnomolekulyarnyye mekhanizmy izmeneniya zashchitnykh funktsiy organizma pri cherepno-mozgovoy travme i popytka lecheniya [Cellular and molecular mechanisms of changes in the protective functions of the body in traumatic brain injury and an attempt at treatment]. Meditsinskiy akademicheskiy zhurnal - Medical Academic Journal, 14, 4, 55-61 [in Russian].

26. Lisyany, N.I., Palamaryova, A.V., \& Lisyany, A.O. (2021). Osoblyvosti rozvytku zapalnykh reaktsii u kirkovykh ta pidkirkovykh viddilakh holovnoho mozku shchuriv pislia lehkoi cherepno-mozkovoi travmy [Peculiarities of development of inflammatory reactions in core and subcortal departments of rats brain after light brain injuryry]. Zdobutky klinichnoi ta eksperymentalnoi medytsyny-Achievements of Clinical and Experimental Medicine, 1, 92-95 [in Ukrainian].

\title{
STUDY OF THE INFLUENCE OF HUMORAL FACTORS OF FETAL NERVOUS STEM CELLS ON THE CYTOTOXIC ACTIVITY OF RATH SPLENOCYTES WITH TRAUMATIC BRAIN INJURY
}

\author{
@M. I. Lisyany, L. M. Belska, A. V. Palamaryova, D. M. Stanetska, A. I. Kliuchnikova \\ SI "A. Romodanov Neurosurgery Institute National Academy of Medical Sciences of Ukraine", Kyiv
}

SUMMARY. In the pathogenesis of trauma, there are, traditionally, 2 phases. The first phase is caused by damage to the brain under the direct action of a traumatic factor, which leads to mechanical damage to the integrity of neurons, glia, blood vessels of the brain. The second phase, where the so-called secondary disorders occur, begins a few hours after TBI and lasts from several days to several weeks, characterized by calcium in neurons, free radical formation, oxidative stress, synthesis of proinflammatory cytokines and the development of immunopathological reactions leading to necrosis. and neuronal apoptosis. One of the approaches to the treatment of the consequences of trauma is cell therapy with various stem cells (SC), and their humoral factors, which have proven to be a promising method of treatment.

The aim - to study the effect on cytotoxin activity of rat splenocytes in the first and 5th day after TBI humoral factors produced in cell culture in vitro by embryonic neuronal cells.

Material and Methods. The work used mature rats $(n=36)$, bred in the vivarium of the State Institution "INH NAMS". All work with experimental animals was carried out in compliance with legal norms and requirements of the Law of Ukraine №3447 IV "On protection of animals from cruel treatment", "European Convention for the protection of vertebrate animals used for research and other scientific purposes" (Strasbourg, 1986), with taking into account the principles of bioethics and biosafety standards. The animals were kept in standard conditions of an accredited vivarium. Traumatic brain injury in rats was modeled according to the recommendations of Romanov GA, and others (2015) for modeling TBI in animals by dropping a load (weighing $100 \mathrm{~g}$ ) from a height of $120 \mathrm{~cm}$ on the head of rats that were anesthetized intraperitoneally $0.5 \mathrm{ml}$ mixtures of ketamine $(70.0 \mathrm{mg} / \mathrm{kg})$ and sedazine $(15 \mathrm{mg} / \mathrm{kg})$ [22]

Determination of cytotoxic activity of spleen cells in rats. The cytotoxic activity of splenocytes against sheep erythrocytes was determined by the spectrophotometric method described [23].

Obtaining fractions of conditioned medium from cultures of embryonic cells of the brain of rats was performed according to the developed method [24]. The brain was removed under sterile conditions from the fruits of ether-anesthetized females (E16-18 days of pregnancy), freed from blood vessels and membranes, and suspended in the medium by repeated picketing [24]. The resulting cell suspensions were seeded on the bottom of plastic Petri dishes and cultured for 48 hours in nutrient medium without embryonic calf serum. Supernatants of brain cell cultures, so-called conditioned media (CS), were used to treat animals with trauma. 
Огляди літератури, оригінальні дослідження, погляд на проблему, випадок з практики, короткі повідомлення

Results. In traumatic brain injury in rats there is an increase in direct and antibody-dependent cytotoxicity of spleen cells, which is registered 24 hours after injury with a gradual further increase to 5 days. A single injection of trophic factors, which are produced in cell culture by embryonic nerve cells in a conditioned environment, rats immediately after injury causes a probable decrease in both types of cytotoxicity. Administration of conditioned media of embryonic nerve cells to rats with trauma for 1, 2, 3 days after injury causes, for 5 days, probable inhibition of increased direct and antibody-dependent cytotoxicity, which indicates the immunosuppressive effect of these trophic factors.

Conclusions. In traumatic brain injury in rats, there is an increase in the cytotoxic activity of splenocytes as early as 24 hours after injury, which may be inhibited by the introduction of trophic factors produced by embryonic cells of the rat brain.

KEY WORDS: traumatic brain injury; splenocytes; cytotoxic activity; embryonic nerve cells. 